\title{
Spotting the Critical Service Quality Determinants in the Ghanaian Retail Banking: Importance and Effects
}

\author{
Geoffrey Bentum-Micah $^{1 *} \quad$ Wenxin Wang $^{1} \quad$ Zhiqiang Ma $^{1} \quad$ Antoinette Asabea-Addo ${ }^{1}$ \\ Sampson A. Atuahene ${ }^{2}$ Victor Bondzie-Micah ${ }^{3} \quad$ Rhoda Afriyie Mensah $^{4} \quad$ Emmanuel B. Boadi ${ }^{1}$ \\ 1.School of Management, Jiangsu University, Zhenjiang 212013, P.R. China \\ 2.School of Finance \& Economics, Jiangsu University, Zhenjiang 212013, P.R. China \\ 3.School of Public Affairs, University of Science and Technology of China, Anhui, P.R. China \\ 4.School of Mechanical Engineering, Nanjing University of Science and Technology, Nanjing, China
}

\begin{abstract}
Critical of the areas in customer-centered marketing paradigms and philosophies, is ensuring that existing customers are satisfied to enable you maintain their loyalty, repurchase and to woo in new clientele. The study examined the critical influences of customer satisfaction in the retail banking of Ghana and its effects on customers' purchasing behavior. The study included 791 clienteles drawn from the sampling population. A cross-sectional survey was used to examine the experience of benefiting from service quality elements, perceived service quality and customers purchasing behavior based on a customized 18 dimensions of SERVQUAL. By means of frequency and mediation analysis, estimates for the direct and indirect effects of benefiting from the service quality influences on perceived service quality and consumer purchasing behavior was assessed. The impacts of evidence of service quality factors on customers purchasing behavior, was partially-mediated by perceived service quality with statistically-significant indirect effect. The results prompted that the banks' aesthetics, cleanliness, communication skills, competence, availability, access and security of their clienteles be prioritized areas they can't afford to fail.
\end{abstract}

Keywords: Service Quality, Determinants, Retail Banking, Customer Satisfaction, Behavioral intentions.

DOI: $10.7176 / \mathrm{EJBM} / 11-27-08$

Publication date:September $30^{\text {th }} 2019$

\section{Introduction}

Satisfaction is a subjective perception and therefore difficult to define (Nasution et al., 2014). It draws its dependency on innumerable factors and diverges from individual to individual and merchandise to merchandise as well. Some main concerns of the satisfaction literature are quality of service, and its value. Quality, according to (Dabholkar, 2015), is the meeting of the needs and expectations of customers. Value, on the other side, is the importance attached a service based on their usage and the sum total paid in interchange for it acquisition (Grönroos and Voima, 2013). These conceptions though different, have over the years been used interchangeably.

The survival and the competitive strength of banks not exclusively but to some large extent resides in the degree of its customer satisfaction, ((Narteh and Kuada, 2014). Quality of service is the only effective instrument that banks can use to survive in the market with regards that they sell homogenous products. Improved quality of service comes with the benefits of competitive advantage, increase in profits and customer retention, as well as high market shares and returns (Hassan et al., 2015). Banks aren't only striving to bid quality service and products, but also seek to maintain existing customer base and attract new ones as well from the ever-growing populace, which, enhances the reputation of the banks with increase in financial performance from the new customers (Kyei and Narteh, 2016).

According to (Chinomona and Sandada, 2013), a very satisfied customer is more likely to be loyal, repurchase and recommend a merchandise or service to family and associates, than a consumer who is just satisfied. Satisfied customers tell about five other people about their satisfaction of a product or service, and that can increase profits by mere word-of-mouth advertisement thereby reducing cost of marketing (Auka, 2012). (Hassan et al., 2015), posits that quality of service and satisfaction are important indicators that cement the connection between organizations and its customers, since the average customer with a problem eventually tells other people about their unfortunate ordeal. Customer satisfaction is principally driven by service quality of a firm from the perspective of its customers (Lusch and Vargo, 2014), and this has empirically informed practitioners of the necessity of developing, communicating, delivering and refining the quality of service to its customers.

The role that banks play in the growth of any country cannot be over-emphasized, hence the banking industry in Ghana, like any other service organization, has the quest to deliver quality service to satisfy its customers amidst fierce competition for market share with its numerous local and overseas competitors. An alarming paradox in the Ghanaian retail banking industry is the amount of reported customer dissatisfaction with the banks, despite large-scale efforts by banks to improve their service to customers (Kyei and Narteh, 2016). This pressure has forced most banks in response to try and advance service quality for example, by lessening 
time spent in queues, improving the reliability and accessibility of ATMs, politeness of face-to-face encounters with customers and even the extension of the availability of electronic and telephone banking as well as banking days (William et al., 2016).

The fiscal system of Ghana is classified into three forms; formal, semi-formal and informal. Banks fall under the formal system and form the institutions which are licensed by Bank of Ghana (World Bank, 2004; Steel and Andah, 2004; Bank of Ghana, 2018). The Central Bank of Ghana, as at January 2019, only twenty three (23) of these Banks had met the minimum capital requirement to operate and has been fully licensed to do so in good standing according to the banking and constitutional laws of the state (Bank of Ghana, 2019). The rural banks are in practice also commercial banks, just that they have a small capital base for startup requirements and cannot go into foreign exchange operations. The (Kadri et al., 2013) posits that Rural banks are unit banks owned by people in the community since they are the shareholders. Their customers are mainly from the communities they operate but however can have opened mobilization Centre's in other major towns and cities. They are primarily set up to increase savings mobilization and credit services to the rural communities not served by commercial and development banks. Development, commercial, merchant and none banking monetary establishments were from their inceptions meant to focus on entirely very different facets of financial transactions. Commercial banks focus on retail services on universal basis, merchant banks fee-based and involved in corporate banking and development banks focuses on medium and long-term financing. But it seems very difficult to draw a borderline between them as they all offer almost the same services. This is because contrary to regulations, these financial institutions are now rather structured based on competition which define the kinds of merchandises and services to sell, and the type of assets and liabilities it can hold and issue (Brigham et al., 2016). None banking financial institutions now based on this notion and precepts, compete with banks with similar monetary mechanisms and services. And to that effect there are no clear variations in the merchandises and services offered by both the none banking and banking institutions (Amoah-Mensah, 2011).

It is empirical that managers might tend to emphasize, quite reasonably, on doing things that will increase customer satisfaction, yet, what customers may notice more are the things that lead to displeasure (Toister, 2012). While many service quality initiatives are in evidence, do managers know which the critical activities are, and do they understand the variation between satisfaction and dissatisfaction creation and which amongst these are the most imperative to their customers. For the above knowledge gap and inconsistency, this study seeks to examine the relationship between the constructs and explore the service quality factors that are considered critical to the Ghanaian bank client and how it affect the clientele behavioral intents.

\section{Methodology}

\subsection{Data Source and Study Population}

The data for the analysis was collected from a cross-sectional study conducted with customers from majority of the listed and licensed banks in Ghana between October and November 2018. The target population for the study is comprised of all individual customers of all the listed and licensed banking companies that operate in Ghana and mandated to do so by the bank of Ghana as at the time of the research. Consent of respondents was acquired using an informed consent form. Willing respondents who were literate in English, and were physically and mentally able to participate in the study at the time of data collection, answered the questions which averagely took between 10 to 20 minutes to complete. (80\%) of the questionnaires were returned, yielding 791 (usable) completed questionnaires. The classification scheme for answering was explained to the customers and they were requested to rate, from 1 to 5 on a Likert type scale, the relative significance of the 18 factors in terms of the service provided by their banks amongst others. Each influence was complemented by an ephemeral description and the categories were also described. The questionnaire items were adopted from previous studies from, (Amoah-Mensah, 2011), (Kwadwo Duodu and Amankwah, 2012; Frank and Theresa, 2011), (Gyasi and Azumah, 2009). The questions were modified to suit the banking industry context in Ghana, and sought respondents' perceptions about overall customer satisfaction, behavioral intents of respondents, and an assessment of service quality dimensions. Unambiguously, the questionnaire had three main parts; the first captured respondents' demographic information in general, the second dealt with overall customer satisfaction based on general service delivery, whilst the last part looked at respondent's insight of service quality and behavior intention with service quality determinants.

\subsection{Statistical Analysis: Study Variables}

The respondents' demographic data, including gender, birth year, educational level (Basic, College, Tertiary), occupation as well the banks they have an account and how they access the account and general customer satisfaction based on service delivery with these respective banks are analyzed and presented below. It goes further to explain to the plainest minimum their frequencies and percentages with respect to responses to the various questions in the questionnaire.

Customers perceived service quality which underpins our understanding of customer satisfaction as 
researchers from the angle of consumers perspective was examined using a previously tested perceived service quality catalogue; SERVQUAL (Johnston et al., 1990; Parasuraman et al., 1988). SERVQUAL is composed by normality a twenty-two items with 5 Likert-type response categories: strongly agree, agree, neutral, disagree, and strongly disagree. After coding and reverse-coding negative items, a sum of Eighteen items were used as a final score. With higher mean scores indicating better-perceived service quality. The internal reliability (measured using Cronbach's alpha) of the SERVQUAL amongst the study population was 0.97 with a factor analysis showing significant constructs at $0.944(<0.001)$.

Customers behavioral intentions towards a service which depicts satisfaction (delight) or not in a service was developed and measured using four overlapping concepts; expectancy, repurchase, recommend and loyalty based on general satisfaction in a product or service. It consists of four items with 5 Likert-type response categories: very unlikely, unlikely, neutral, likely and very unlikely. After coding and reverse-coding negative items, the sum of the four items were used as a final score with higher mean scores indicating better-perceived service quality and a likely positive display of the constructs of the behavioral intents. The internal reliability (measured using Cronbach's alpha) of the constructs amongst the study population was 0.87 . With its test of analysis of variance showing a high significant value of an error margin at less than $1 \%(<0.001)$.

The researchers described the respondent's characteristics using mean and standard deviations or frequencies and percentages. Using median-cutoff points, the researcher's dichotomized the SERVQUAL scores into highs and lows on customers perceived service quality. Then, we performed bivariate evaluates to examine the relationship between each participant characteristic and behavioral intents score. We used four separate regression models to examine a hypothesized mediation effects amongst the constructs of the study. The mediation analysis was performed using the traditional Baron \& Kenny approach.

Figure: 1

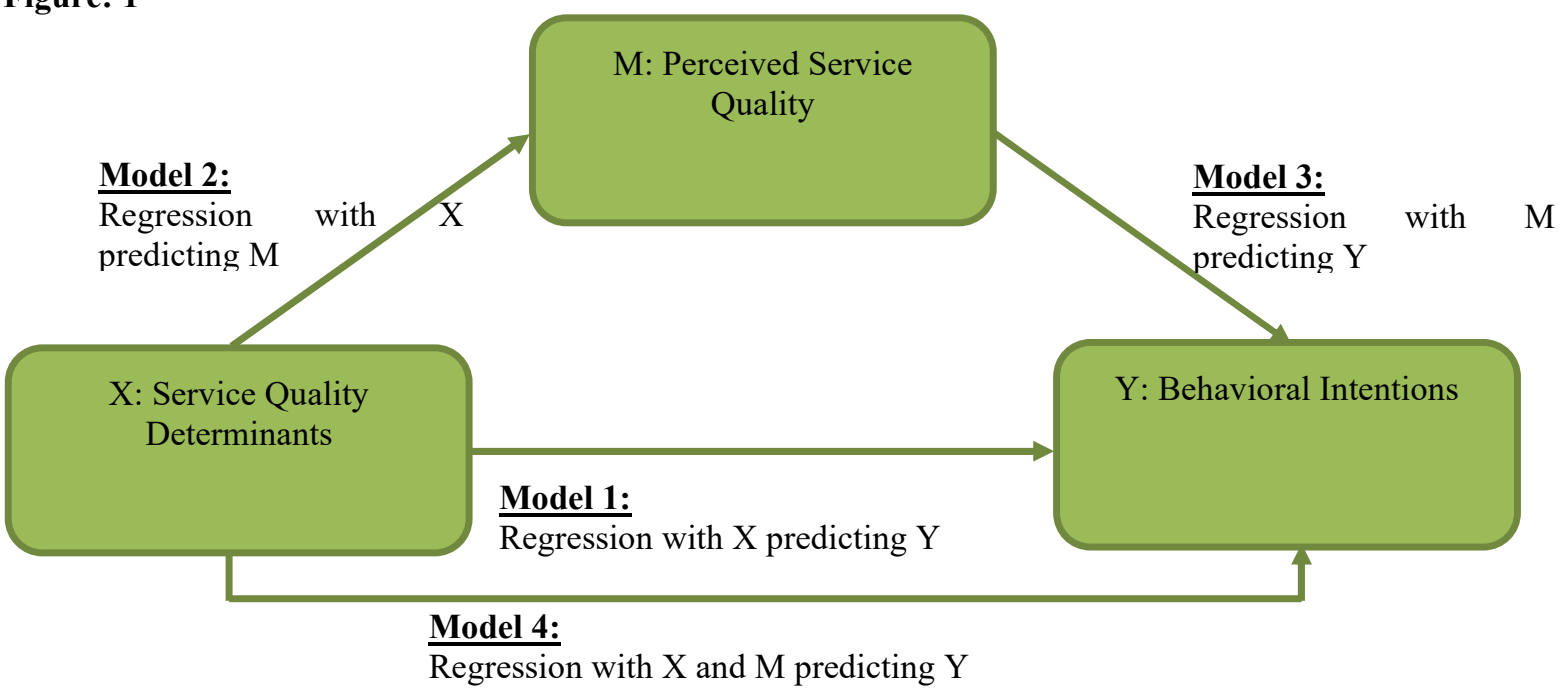

Figure 1: Tested mediation model depicting perceived service quality as a mediator $(\mathrm{M})$ of the association between consumers' experience with the Service quality determinants (X) and customer behavioral intents (Y)

The first model tested the effect of the experience of service quality determinants on the behavioral intents of customers. The second model tested the effect of the service quality determinants experience on customers' perceived service quality. The third model tested the effect of consumers' perceived service quality on behavioral intents of customers. The last model tested the effects of service quality experience and consumers' perceived service quality on behavioral intents of customers. The indirect effect, estimated using the standardized regression coefficients, was tested using the Sobel-Goodman mediation test approach. All statistical analyses were performed using Stata 15.1

\section{Results}

The study included a total of 791 respondents. A fraction of 389(49.18\%) been males and 402(50.82\%) been females. The "vulnerable" as classified by the aged; 50years above in the study represented $(2.78 \%)$ and those below 20years $(4.42 \%)$ respectively out of the total respondent that were approached. On the other hand, the "youth" segregated by active youth; 20-29years (58.15\%) and 30-39years (28.57\%) respectively with the passive youth; 40-49 years $(6.07 \%)$ of the total respondents. This distribution was very symbolic of the research setting. Proportionally, the number of respondents between the ages of 20-29years and 30-39years representing the active youth outstripped the other age categorization to mean dominant users of the banks. The "vulnerable" groups indicated passive use of the banks with regards to the fact that they either seldom visit the banking halls 
or delegated due to their vulnerability.

Table 1: Demographic Parameters of Participants and Attitudinal Characteristics in overall and by perceived service quality

\begin{tabular}{|c|c|c|c|c|c|}
\hline \multirow{3}{*}{ Customer Characteristics } & \multicolumn{5}{|c|}{ Mean (SD) or Frequency (\%) Statistics } \\
\hline & \multicolumn{5}{|c|}{$($ Overall $\mathrm{N}=791)$} \\
\hline & Frequency & Percentage & Mean & Standard Error & $p$ \\
\hline Gender & & & .5082174 & .5002488 & \multirow{3}{*}{$<0.001^{*}$} \\
\hline Male & 389 & $(49.18 \%)$ & & & \\
\hline Female & 402 & $(50.82 \%)$ & & & \\
\hline Age group & & & 1.446271 & .7903424 & \multirow[t]{6}{*}{$<0.001^{*}$} \\
\hline Below 20years & 35 & $(4.42 \%)$ & & & \\
\hline 20-29years & 460 & $(58.15 \%)$ & & & \\
\hline 30-39years & 226 & $(28.57 \%)$ & & & \\
\hline 40-49years & 48 & $(6.07 \%)$ & & & \\
\hline 50years above & 22 & $(2.78 \%)$ & & & \\
\hline Educational Level & & & 1.858407 & .5302753 & \multirow[t]{5}{*}{$<0.001^{*}$} \\
\hline Basic/Primary & 28 & $(3.54 \%)$ & & & \\
\hline Secondary/college & 91 & $(11.50 \%)$ & & & \\
\hline Tertiary & 637 & $(80.53 \%)$ & & & \\
\hline Other & 35 & $(4.42 \%)$ & & & \\
\hline Occupation & & & 1.060683 & .9244138 & \multirow[t]{5}{*}{$<0.001^{*}$} \\
\hline Civil Servant & 236 & $(29.84 \%)$ & & & \\
\hline Student & 350 & $(44.25 \%)$ & & & \\
\hline Businessman/Woman & 126 & $(15.93 \%)$ & & & \\
\hline Other & 79 & $(9.99 \%)$ & & & \\
\hline Type of Bank & & & .3678887 & .6617434 & \multirow[t]{5}{*}{$<0.001^{*}$} \\
\hline Commercial & 581 & $(73.45 \%)$ & & & \\
\hline Savings/Rural & 129 & $(16.31 \%)$ & & & \\
\hline Merchant/Development & 81 & $(10.24 \%)$ & & & \\
\hline Other & - & - & & & \\
\hline How often do you use the Bank & & & 1.705436 & .8673885 & \multirow[t]{5}{*}{$<0.001^{*}$} \\
\hline Daily & 100 & $(12.64 \%)$ & & & \\
\hline Weekly & 148 & $(18.71 \%)$ & & & \\
\hline Monthly & 428 & $(54.11 \%)$ & & & \\
\hline Other & 115 & $(14.54 \%)$ & & & \\
\hline How do you deal with the Bank & & & 2.437421 & 2.395315 & \multirow[t]{8}{*}{$<0.001^{*}$} \\
\hline Office & 328 & $(41.47 \%)$ & & & \\
\hline Internet & 50 & $(6.32 \%)$ & & & \\
\hline Telephone & 12 & $(1.52 \%)$ & & & \\
\hline Office \& Telephone & 86 & $(10.87 \%)$ & & & \\
\hline Office \& Internet & 127 & $(16.06 \%)$ & & & \\
\hline Internet \& Telephone & 40 & $(5.06 \%)$ & & & \\
\hline Office, Internet \& Telephone & 148 & $(18.71 \%)$ & & & \\
\hline
\end{tabular}

Source: Fieldwork, $2018 \quad$ SD. $=$ Standard Error, $(\mathrm{N})=$ Population Size $\quad * p<0.05$

The data on the educational background of respondents as depicted by Table 1 posits that, the number of persons who had Tertiary/College education representing $(80.53 \%)$ and $(11.50 \%)$ respectively of the total sample, patronized the services of banks more than those with Basic/Primary and Other forms of education. This also had a positive relationship with the fact that most of these individuals formed the active youths of the Ghanaian economy. As indicated by the age group analysis above these individuals are backed by their financial strength to access the services that the banks provide. The results indicated that as many that had some level of continues income patronized the services of the bank, again these were the active youth and formed the majority of the population. Although students were found to patronize the services of banks more, the businessmen/women as well as the civil servants were not left out. Civil/government workers make majority of the state workers from common ideology; but the research found out that although this was true, they hardly visited the banks like the students do and most often than not, did just once in a month because that was when they received their monthly salary from the Accountant and controller general; a body set up by the state to manage civil workers' pay. Customers as indicated by the Table 1 preferred commercial banks to the savings and merchant banks as posited 
by their respective percentage margins of $(73.45 \%),(16.3 \%)$ and $(10.2 \%)$ respectively. These three banks although seen subjectively by customers as providing similar services, commercial banks are seen as accessibly relative, since they have many branches throughout the country. Subjectively, the number of times customers transact business with their banks gives a hint about the level of their satisfaction and loyalty to the bank. Office was the main means through which the majority of the respondents or customers adopted in transacting business with the banks. In fact, internet is seen as an 'urban commodity' and a few affluent ones use it for normality as the case maybe.

Table 2: Results from the Multivariate Regression Models Analysis

\begin{tabular}{|l|c|c|c|c|c|c|c|c|}
\hline & \multicolumn{2}{|c|}{$\begin{array}{c}\text { Model 1: Customer } \\
\text { behavioral intentions }\end{array}$} & \multicolumn{2}{c|}{$\begin{array}{c}\text { Model 2: Service } \\
\text { quality }\end{array}$} & \multicolumn{2}{c|}{$\begin{array}{c}\text { Model 3: Customer } \\
\text { behavioral intentions }\end{array}$} & \multicolumn{2}{c|}{$\begin{array}{c}\text { Model 4: Customer } \\
\text { behavioral intentions }\end{array}$} \\
\hline & $\beta$ & $P$-Value & $\beta$ & $P$-Value & $\beta$ & \multicolumn{1}{c|}{-Value } & $\beta$ & $P$-Value \\
\hline Intercept & 4.82 & $<0.001^{*}$ & 7.32 & $<0.001^{*}$ & -1.33 & $<0.001^{*}$ & -1.74 & $<0.001^{*}$ \\
\hline $\begin{array}{l}\text { Service quality } \\
\text { Determinants }\end{array}$ & .061 & $<0.001^{*}$ & .047 & $<0.001^{*}$ & & N/A & 0.19 & $<0.001^{*}$ \\
\hline $\begin{array}{l}\text { Perceived service } \\
\text { quality }\end{array}$ & \multicolumn{7}{|c|}{ N/A } & \multicolumn{2}{c|}{ N/A } & 0.94 & $<0.001^{*}$ & 0.90 & $<0.001^{*}$ \\
\hline
\end{tabular}

$\beta=$ Standardized regression coefficients $* p<0.05$

Table 2 shows the results for the fixed effects from the regression analyses testing the mediation model. From the table, evidence of benefiting from the service quality determinants was positively associated with customer perceived service quality (Model 2, $\beta=0.47, p<0.001$ ) and customers behavioral intents (Model $1, \beta$ $=0.61, p<0.001)$. Model 3 also suggested that, perceived service quality of consumers was positively associated with consumer's behavioral intents in this model $(\beta=0.94, p<0.001)$. Also, the relationship between the evidence of benefiting from the service quality determinants and the customer behavioral intents still remained statistically significant $(\beta=0.19, p<0.001)$ after controlling for perceived service quality, therefor suggesting a partial mediation effect of the service quality determinants and perceived service quality on clientele behavioral intents.

Figure: 2

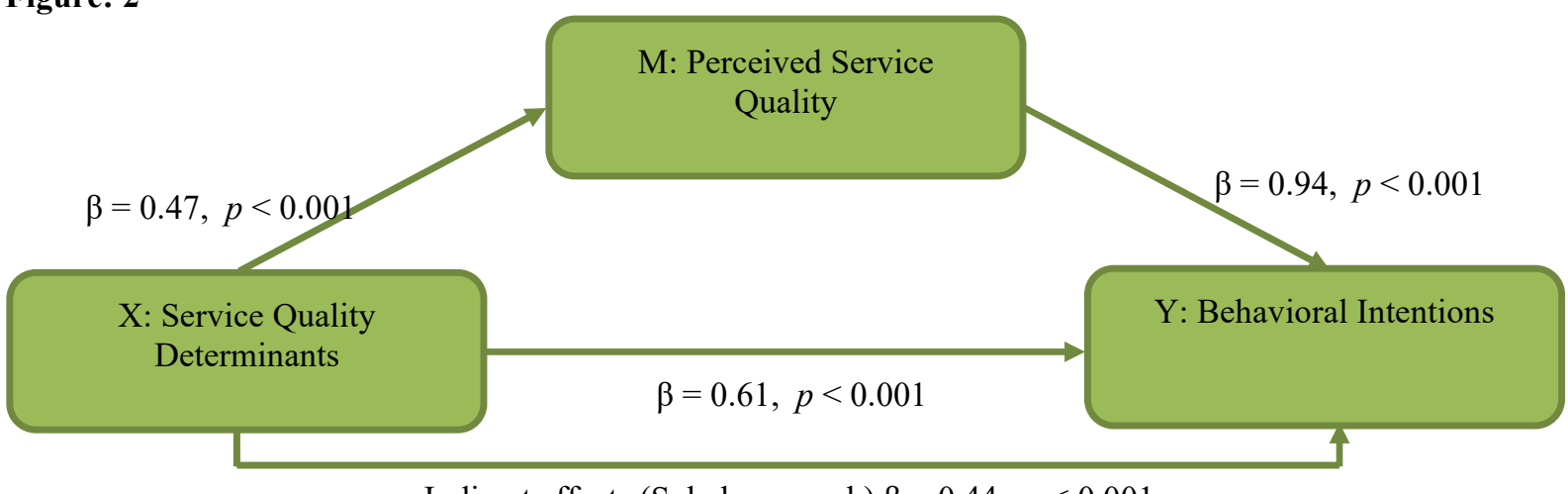

Indirect effects (Sobel approach) $\beta=0.44, p<0.001$

Figure 2: Path model depicting perceived service quality as a mediator $(\mathrm{M})$ of the association between consumers' experience with the Service quality determinants $(\mathrm{X})$ and customer behavioral intents $(\mathrm{Y})$

Figure 2, demonstrates the partial mediation between the evidence of benefiting from the service quality determinants and clientele behavioral intents by customer's perceived service of quality. The Sobel test exhibited that the indirect effect of evidence of benefiting from the service quality determinants and clientele behavioral intents was statistically-significant (indirect effect $=0.42, p<0.001$ ) with the mediation effect of perceived service quality being statistically significant with approximately $68 \%$ of the total effect of evidence of benefiting from the service quality determinants on clientele behavioral intents been mediated.

Respondents were presented with a Hypothesis developed using the SERVQUAL model developed by Johnston et al, as basis for testing how satisfied or dissatisfied they would be if they were fully conscious of the influences that drive customer satisfaction. Based on these determinant's, customers could best evaluate their service experience by their respective banks and how the banks can better improve such service delivery in the long run. The model is an 18 factors of service quality determinants providing perhaps the most inclusive and detailed list of elements of service quality (Ali and Raza, 2017; Johnston, 1995). Given the determinants' and their tendency to dissatisfy or delight the customers, the respondents were inquired to specify on a scale of 1-5 how satisfied, indifferent or dissatisfied they would be if these factors were evident. The respondent's frequencies of mention, classified by their satisfying, dissatisfying and indifferent effect as well as their means 
(importance) to the customers, are normalized and summarized in Table 3. Each factor's average importance on a five-point scale ( $5=$ very important, $1=$ unimportant) are also shown in Table 3.

Table 3: Customer Satisfaction Based on the Service Quality Determinants

\begin{tabular}{|c|c|c|c|c|c|c|c|c|c|}
\hline \multirow[t]{2}{*}{$\begin{array}{l}\text { Service Quality } \\
\text { Determinants }\end{array}$} & \multicolumn{2}{|c|}{ Dissatisfying } & \multicolumn{2}{|c|}{ Indifferent } & \multicolumn{2}{|c|}{ Delight } & \multicolumn{3}{|c|}{$\begin{array}{l}\text { Importance } \\
\text { (Effects) }\end{array}$} \\
\hline & $\begin{array}{l}\text { Cum. } \\
\text { Freq. }\end{array}$ & $\begin{array}{l}\text { Percent } \\
(\%)\end{array}$ & $\begin{array}{l}\text { Cum. } \\
\text { Freq. }\end{array}$ & $\begin{array}{l}\text { Percent } \\
(\%)\end{array}$ & $\begin{array}{l}\text { Cum. } \\
\text { Freq. }\end{array}$ & $\begin{array}{l}\text { Percent } \\
(\%)\end{array}$ & $\begin{array}{l}\text { Total } \\
\text { Freq. }\end{array}$ & $\begin{array}{l}\text { Total } \\
\text { (Percent) }\end{array}$ & $\begin{array}{l}\text { Mean } \\
\text { Value }\end{array}$ \\
\hline Access & 98 & 12.4 & 113 & 14.3 & 580 & 73.3 & 791 & 100 & 3.79 \\
\hline Aesthetics & 99 & 12.5 & 174 & 22.0 & 518 & 65.5 & 791 & 100 & 3.67 \\
\hline Attentive & 172 & 21.7 & 174 & 22.0 & 445 & 56.3 & 791 & 100 & 3.50 \\
\hline Availability & 119 & 15.0 & 155 & 19.6 & 517 & 65.4 & 791 & 100 & 3.69 \\
\hline Care & 161 & 20.4 & 159 & 20.1 & 471 & 59.6 & 791 & 100 & 3.52 \\
\hline Cleanliness & 97 & 12.3 & 156 & 19.7 & 538 & 68.0 & 791 & 100 & 3.78 \\
\hline Comfort & 147 & 18.6 & 156 & 19.7 & 488 & 61.7 & 791 & 100 & 3.59 \\
\hline Commitment & 140 & 17.7 & 158 & 20.0 & 493 & 62.3 & 791 & 100 & 3.64 \\
\hline Communication & 122 & 15.4 & 162 & 20.5 & 507 & 64.0 & 791 & 100 & 3.68 \\
\hline Competence & 98 & 12.4 & 165 & 20.9 & 528 & 66.8 & 791 & 100 & 3.68 \\
\hline Courtesy & 137 & 17.3 & 148 & 18.7 & 506 & 63.9 & 791 & 100 & 3.60 \\
\hline Flexibility & 174 & 22.0 & 171 & 21.6 & 446 & 56.3 & 791 & 100 & 3.51 \\
\hline Friendliness & 130 & 16.4 & 194 & 24.5 & 467 & 59.0 & 791 & 100 & 3.64 \\
\hline Functionality & 170 & 21.5 & 130 & 16.4 & 491 & 62.1 & 791 & 100 & 3.53 \\
\hline Integrity & 139 & 17.6 & 158 & 20.0 & 494 & 62.4 & 791 & 100 & 3.59 \\
\hline Reliability & 174 & 22.0 & 141 & 17.8 & 476 & 60.2 & 791 & 100 & 3.53 \\
\hline Responsiveness & 197 & 24.9 & 148 & 18.7 & 446 & 56.4 & 791 & 100 & 3.39 \\
\hline Security & 120 & 15.2 & 132 & 16.7 & 539 & 68.1 & 791 & 100 & 3.73 \\
\hline
\end{tabular}

Source: Field Work, $2018 \quad$ ** Cum=Cumulative Freq.=Frequency Distribution

Table 3 shows that majority of the influences spread across three of the 1-5 Likert scale developed. A symbolic depiction that all the factors were averagely felt to have at minimum some importance classified by (low, average and High importance). However, some of the respondents were of the view that some of the influences for example; Attentiveness (The extent to which service staff give the impress or show the willingness to serve/help the customer), Responsiveness (The speed of service delivery; the ability of the service providers to respond quickly to customer service requests, with minimal waiting and queue up time.), Reliability (The regularity of performance of service staff, products and facilities, the punctuality of service delivery and the ability of the service providers to keep to agreements made with the customers.), Care (How emotionally comfortable the customer is made by the service staff rather than physical comfort in the banking hall) and Flexibility; the willingness of the contact staff to amend the nature of a service to meet customer needs, were factors they felt were subjectively indifferent (more impartial in their effect) or had little importance at all to them.

The Table 3 also submits that any factor(s) lying below a mean of 3.59 (low importance), such as Attentiveness, Function, Flexibility, Reliability, Care and Responsiveness as posited above are worthy of minimal time and energy and so should be provided to a basic standard as the case and demand maybe. These qualities are not essentially and readily expected by the customers from the research findings, but it goes further to advice that if such services are delivered on or without the request of customers; could significantly impact customer views of the service provided with a concept of a plus.

Comfort (How comfortable is the service environment and facilities?), Integrity (The fairness, honesty and justice with which the service providers treat the customers.), Courtesy (The propriety, respect and politeness the customer is shown by usually the contact staff in the rendering of service), Commitment (To what extent is the staff committed to their work, the pride and satisfaction, including the diligence they attach to the work) and Friendliness (The warmth, cheerfulness and personal approach of the service or staff that makes the customer feel welcomed), are areas the research found to be important and cannot be overlooked come what may. These qualities bridged the gap between the low and high importance of the service quality of the consumers from the customers perspective.

Similarly, Aesthetics (Extent to which components of the service are pleasing to the customer, including the appearance of service environment, facilities, goods and staff.), Competence (The general ability of the staff to do a good job. The proficiency and the efficiency with which the service is rendered with the right processes and the performance of customer instructions.), and Communication (The ability of the service staff to communicate with the customer in a way they best understand.), were equally very relevant factors that cannot be overlooked 
if the banks want to build a reputable notion of customer satisfaction based on their quality of service provision.

Access (Physical location of service providers with clarity of route), Availability; of service products and contact staff with commitment of the staff to their work, Security (The confidentiality, safety and the welfare of the customer including their possessions in and around the service area during the participation in or benefiting from the service process) and Cleanliness (How tidy, neat or clean is the service environment, contact staff, facilities and the tangible components of the service package.) from the Table 3 is suggested that, organizations cannot afford to fail in these capacities.

Whereas the study found Attentiveness/Helpfulness, Care, Comfort and Courtesy as more unbiased in their effect and delivery, Aesthetics, Cleanliness, Communication, Competence, Availability, Access and Security are seen as vibrant qualities of a banking service. Failing in these aspects will result in a weighty notch of dissatisfaction. These high-importance factors such as Aesthetics, Cleanliness, Communication, Competence, Availability, Access and Security are extents to which banks may grow a reputation for excellence in the Ghanaian retail banking industry.

Still, the study also suggested that, the critical satisfiers; the factors that may delight customers more tend to be more of the intangible aspects of the service than its tangible aspects. However, the sources of dissatisfaction seem to be related with either the more noticeable aspects of service or systemic issues than the intangible aspects.

\section{Discussion}

Using a cross-sectional data from listed retail banks, the study precisely sought to spot the critical determinants of customer satisfaction in the retail banking industry of Ghana: examine it influences on consumers' behavioral intentions, and to make recommendations to enhance both customers and management level of satisfaction as a whole. The study showed that the evidence of benefiting of the service quality determinant's leads to higher perceived service quality and hence a greater chance of a favorable customer behavioral intent. The conducted mediation analysis in the study supportive of previous studies, indicated that both the evidence of the service quality determinants and perceived service quality are predictors of customers behavioral intents: repurchase, recommend and loyalty to the service, and the effect of the evidence of the service quality determinants on the consumers behavioral intents was partially-mediated through the customers perceived service quality.

The study found commercial and savings/rural banks to be the major banks that people patronized the most respectively. This is because they are seen to be relatively accessible since they have many branches throughout the country and office or the banking hall was the main means used by customers in transacting business with the banks. This the findings intimate its convenience for the consumers. Telephones are expensive and internet is difficult to come by and so were seen as premium services for the affluent of society.

The service quality determinants are in practice, intended to help bridge the difference gap between expectations and perceptions of a customer's service experience and this study generally supportive of this, suggests a positive impact of it evidence on perceived service quality. (Wang et al., 2014; Eboli and Mazzulla, 2011; Zeithaml, 1988), Posits however that, contrasting of objective service quality, perceived service quality is subjective and can be appraised as either high or low as the case maybe, based on the consumers decision.

As hypothesized, the study prompted seven critical quality determinants; aesthetics, cleanliness, communication, competence, availability, access and security which were found to be highly correlated, hence adding to the pool of academic debate and knowledge concerning the universality of the factors of SERVQUAL. The seven critical factors also exhibited a subjective character in this study, meaning they were seen differently by customers though in the same banking industry and hence providing a strong evidence that perceptions of the quality dimensions of banks' services vary and depend on numerous factors. The critical factors suggest that although being friendly, having a clean banking environ or courteous staff may not necessarily make the customer delighted, but are expanses where banks cannot make blunders, they are very important (High) to customers and are hypothetically highly dissatisfying factors. Time and genuine energy spent in these extents would likely reduce the time and sweat spent dealing with dissatisfied customers.

Numerous studies have focused on the service quality determinants(Johnston, 2013; Lee et al., 2000; Hu et al., 2014; Srivastava, 2015; Wang et al., 2014) however, the critical of these determinants to the consumers are still understudied. Connecting the relationship of these critical factors of service quality on consumers satisfaction and consumers behavior intents, this study adds worth to existing studies showing that spotting evidence of the critical service quality determinants to the consumer and its benefits serves as an enhancement to perceived service quality and thereby build a more favorable clientele behavioral intents in the Ghanaian retail banking setting.

There are some limitations in this present study. The key independent variable of the study: the critical service quality determinants, asked the customers about events that has happened in time past, and thereby implying time factor which could vary hence over time from when they first experienced it. Also, the lack of baseline measures of the perceived service quality and customers behavioral intents limits the study's 
implication about the theorized causation. The data used for the analysis relied on self-report from the respondent's, which could not be verified (an example, if they indeed had an encounter with the service quality determinants or not). Further, the study left little room for the long-term examination of the determinants on customers behavioral intents, and hence the long-term follow-up is recommended for future research and evaluation of the model's impact. Even though the study has its limitations, it adds value to the pool of knowledge as its one of the few studies that has examined the spotting the critical factors amongst the varied service quality determinants adopted for exploring service quality.

It is recommended that showing emotions of attentiveness and empathy are not things that can be scripted for the staff; friendliness for customer day-to-day encounters and hence banks must challenge themselves to exhibit unpretentious warmth and empathy to their customers. Also, having polite and courteous staff is little consolation for a consumer that feels highly dissatisfied because of an integrity, competence or security-type error, this is to say that all the factors identified are important but some critical than others.

Security, access, availability, competence, communication and cleanliness were factoring this study found to be distinctive achievers of advantage for the bank. These are dimensions which are considered to be very important by customers and are the factors which provide the greatest opportunity to delight customers.

\section{Conclusion}

This study together with other previous studies on the effects of satisfaction on consumer behavioral intentions suggests that the critical service quality determinants has the potential of improving consumer intentions through improving perceived service quality of consumers. This study has provided a framework to help assess the likely impact of a service quality initiative in relation to its effect on behavioral intensions of customers. Though this study provides supportive evidence of its hypothesis as yielding positive effects on consumer behavioral intentions through improved, perceived service quality, this study is limited by its study design, and hence a long-term follow-up is recommended for future research and evaluation of the model's impact. The study suggests that there are some areas which are not worth much attention, any time and money, beyond a basic provision, put into such areas for example flexibility and care this study found, would be better redirected elsewhere.

\section{Acknowledgments}

The Authors would like to gratefully acknowledge the contributions of Professor LIU Shengfu and Professor LI Tai of Hubei University of Technology; School of Economics \& Management for their immense advice and scholarly directions in relation to the completion of this paper.

\section{Bibliography}

Ali M and Raza SA. (2017) Service quality perception and customer satisfaction in Islamic banks of Pakistan: the modified SERVQUAL model. Total Quality Management \& Business Excellence 28: 559-577.

Amoah-Mensah A. (2011) Customer satisfaction in the banking industry: a comparative study of Ghana and Spain: Universitat de Girona.

Auka DO. (2012) Service quality, satisfaction, perceived value and loyalty among customers in commercial banking in Nakuru Municipality, Kenya. African Journal of Marketing Management 4: 185-203.

Bank of Ghana. (2018) Banking Acts. Available at: https://www.bog.gov.gh/banking/banking-acts.

Bank of Ghana. (2019) List of licensed banks, representative offices \& their registered offices in Ghana as at January 2019. Available at: https://www.bog.gov.gh/supervision-a-regulation/register-of-licensedinstitutions/banks.

Brigham EF, Ehrhardt MC, Nason RR, et al. (2016) Financial Managment: Theory And Practice, Canadian Edition: Nelson Education.

Chinomona R and Sandada M. (2013) Customer satisfaction, trust and loyalty as predictors of customer intention to re-purchase South African retailing industry. Mediterranean Journal of Social Sciences 4: 437.

Dabholkar PA. (2015) How to improve perceived service quality by increasing customer participation. Proceedings of the 1990 academy of marketing science (AMS) annual conference. Springer, 483-487.

Eboli L and Mazzulla GJTP. (2011) A methodology for evaluating transit service quality based on subjective and objective measures from the passenger's point of view. 18: 172-181.

Frank K and Theresa A. (2011) An Analysis and Assessment of Customer Satisfaction with Service Quality in Insurance Industry in Ghana. Master's Thesis, Lulea University of Sweden.

Grönroos C and Voima P. (2013) Critical service logic: making sense of value creation and co-creation. Journal of the academy of marketing science 41: 133-150.

Gyasi S and Azumah K. (2009) An Assessment and Analysis of Customer Satisfaction with Service Delivery of Mobile Telecommunication Networks within Ghana. Masters Thesis, LTU, Sweden.

Hassan RS, Nawaz A, Lashari MN, et al. (2015) Effect of customer relationship management on customer 
satisfaction. Procedia Economics and Finance 23: 563-567.

Hu JH, Brown SA, Thong JYL, et al. (2014) Determinants of service quality and continuance intention of online services: The case of eTax. 60: 292-306.

Johnston R. (1995) The determinants of service quality: satisfiers and dissatisfiers. International journal of service industry management 6: 53-71.

Johnston R, Silvestro R, Fitzgerald L, et al. (1990) Developing the determinants of service quality. Proceedings of the 1st International Research Seminar in Service Management. La Londes les Maures June.

Johnston RJIJoSIM. (2013) The determinants of service quality: satisfiers and dissatisfiers. 6: 53-71.

Kadri A-BY, Bunyaminu A and Bashiru S. (2013) Assessing rural banks effectiveness in Ghana. International Business Research 6: 140.

Kwadwo Duodu F and Amankwah T. (2012) An analysis and assessment of customer satisfaction with service quality in insurance industry in Ghana.

Kyei DA and Narteh B. (2016) Relationship Marketing Practices and Customer Satisfaction in the Ghanaian Banking Sector. International Journal of Bank Marketing 12: 15-23.

Lee H, Lee Y and Yoo DJJoSM. (2000) The determinants of perceived service quality and its relationship with satisfaction. 14: 217-231.

Lusch RF and Vargo SL. (2014) Evolving to a new dominant logic for marketing. The Service-Dominant Logic of Marketing. Routledge, 21-46.

Narteh B and Kuada J. (2014) Customer Satisfaction with Retail Banking Services in Ghana. Thunderbird International Business Review 56: 353-371.

Nasution RA, Sembada AY, Miliani L, et al. (2014) The customer experience framework as baseline for strategy and implementation in services marketing. Procedia-Social and Behavioral Sciences 148: 254-261.

Parasuraman A, Zeithaml VA and Berry LL. (1988) Servqual: A multiple-item scale for measuring consumer perc. Journal of retailing 64: 12.

Srivastava C. (2015) Determinants of Service Quality in Cross Cultural Research: A Meta-Analytic Perspective.

Steel WF and Andah DO. (2004) Micro and Rural Finance in Ghana: Evolving Industry and Approaches to Regulation.

Toister J. (2012) Service failure: The real reasons employees struggle with customer service and what you can do about it: AMACOM Div American Mgmt Assn.

Wang YS, Wang YM, Lin HH, et al. (2014) Determinants of user acceptance of internet banking: An empirical study. 4: 501-519.

William O, Appiah EE and Botchway EA. (2016) Assessment of customer expectation and perception of service quality delivery in Ghana commercial bank. Journal of Humanity 4: 81-91.

World Bank. (2004) Micro and Rural Finance in Ghana: Evolving Industry and

Approaches to Regulation, Findings 234.

Zeithaml VAJJoM. (1988) Consumer perceptions of price, quality, and value: A means-end model and synthesis of evidence. 52: 2-22.

\section{ACCESS}

Appendix

\section{Definition of the Determinants}

Physical location of service, ease of finding one's way around the service environment and clarity of route.

\section{AESTHESTICS}

Extent to which components of the service are pleasing to the customer, including the appearance of service environment, facilities, goods and staff.

\section{ATTENTIVE/HELPFULNESS}

The extent to which service staff provide help to the customer; give the impression or show the willingness to serve the customer.

AVAILABILITY

How readily accessible are the service products and contact staff. This includes the availability of the products and staff to the customer.

\section{CARE}

The patience, sympathy, concern and consideration the customer is shown by the staff; how emotionally comfortable the customer is rather than physical comfort.

\section{CLEANLINESS}

How tidy, neat or clean is the service environment, contact staff, facilities and the tangible components of the service package.

\section{COMFORT}

How comfortable is the service environment and facilities? 


\section{COMMITMENT}

To what extent is the staff committed to their work, the pride and satisfaction, including the diligence they attach to the work.

\section{COMMUNICATION}

The ability of the service staff to communicate with customer in a way they best understand; the clarity, completeness and accuracy of both verbal and written information relayed to the customer and the ability to listen to and understand the customer.

\section{COMPETENCE}

The general ability of the staff to do a good job. The expertise, skill and the professionalism with which the service is rendered. Correct procedures and the execution of customer instructions.

\section{COURTESY}

The propriety, respect and politeness the customer is shown by usually the contact staff in the rendering of service.

\section{FLEXIBILITY}

The willingness and the ability of the service provider or contact staff to amend or change the nature of a service to meet customer needs.

\section{FRIENDLINESS}

The warmth, cheerfulness and personal approach of the service or staff that makes the customer feel welcomed.

FUNCTIONALITY

How quickly serviceable and fit are the service products/goods and facilities?

INTEGRITY

The fairness, honesty and justice with which the service providers treat the customers.

\section{RELIABILITY}

The consistency of performance of service staff, products and facilities, the punctuality of service delivery and the ability of the service providers to keep to agreements made with the customers.

\section{RESPONSIVENESS}

The speed and timeliness of service delivery; the ability of the service providers to respond promptly to customer service requests, with minimal waiting and queuing time.

\section{SECURITY}

The confidentiality, safety and the welfare of the customer including their possessions in and around the service area during the participation in or benefiting from the service process. 